\title{
ДО ПИТАННЯ ФОРМУВАННЯ ТА ВИКОРИСТАННЯ БЮДЖЕТНОГО ПОТЕНЦАЛУ В КОНТЕКСТІ СОЦІАЛЬНО-ЕКОНОМІЧНОГО РОЗВИТКУ УКРАЇНИ
}

\begin{abstract}
В статті досліджуються теоретико-методологічні аспекти формування і використання бюджетного потенціалу в контексті соціально-економічного розвитку Украйни. Зазначено, щчо питання формування $i$ використання бюджетного потенціалу, не дивлячись на численні наукові праці, ще не отримали належного наукового обтрунтування $і$ вирішення. Серед науковиів існують різні погляди $і$ немає єдиної думки щудо визначення поняття «бюджетний потенціал», так само, як нема його $і$ в Бюджетному кодексі України. Між тим, управління бюджетним потенціалом не вирізняється комплексністю підходу щзодо його наповнення, відсутня оиінка використання та системність при розв'язанні проблем соціально-економічного розвитку. Автором обтрунтовано необхідність при використанні бюджетного потенціалу розподіляти одержані результати за двома критеріями: реалізованими та «нереалізованими» можливостями. Такий підхід дасть змогу об'єктивно оцінювати як здобутки, так $i$ аналізувати прорахунки при використанні бюджетного потенціалу. Крім того, автор вніс поняття «прихованого резерву», який в силу різних обставин (корупиії, иахрайства) не приймає участі в формуванні бюджетного потенціалу, однак $е$ важливим чинником його наповнення та сприяє самодостатності і незалежності бюджету.
\end{abstract}

Ключові слова: бюджет, економічний простір, бюджетна політика, фінансові ресурси, державий бюджет, фінанси, місиеві бюджети, бюджетний потенціал, інститути

Постановка проблеми. Сьогоднішня трансформація економіки України, демонополізація, децентралізація, удосконалення системи фінансового управління, направлені на підвищення ефективності використання ресурсів, в тому числі бюджетних. Бюджет 3 його фінансами є найбільш рухливим ресурсом, який визначає динаміку соціально-економічного розвитку. В бюджетах усіх рівнів зосереджений потужний потенціал, який використовується на стратегічних та поточних напрямках, стимулюванні внутрішнього попиту, запобіганні зовнішнім ризикам.

Підвищення можливостей бюджетного потенціалу, об'єктивне відображення показників, пошук «прихованих» резервів, раціональне використання - ось далеко не повний перелік актуальних питань. Адже, в ринковій економіці високі прибутки і економічну вигоду отримує той, хто ефективно використовує ресурси i бюджетний потенціал.

Багатоаспектність проблематики бюджетного потенціалу i низка проблем в сфері його формування та використання зумовили необхідність дослідження в цій царині і логіку викладення матеріалу.

Аналіз останніх досліджень і публікацій. Сутність бюджетного потенціалу, механізмів

(C) Радіонов Юрій Денисович, к.е.н., начальник відділу адаптації та імплементації міжнародних стандартів, моніторингу і аналізу у сфері державного фінансового контролю Рахункової палати України, тел.: +380675976557, e-mail: radud@ukr.net його визначення, формування, ефективності використання $\epsilon$ сферою досліджень багатьох вчених. Так, Бондарева О.Г. [4], Волковський С.І. [9], Жебчук Р.Л. [5], Люта О.В. [8], Педченко Н.С. [7] та ін. у своїх працях досліджують як теоретичні, так і методологічні аспекти бюджетного потенціалу.

Виділення невирішених проблем. Незважаючи на вагомі здобутки вчених-економістів, низка теоретико-методологічних, а також практичних питань щодо особливостей формування та використання бюджетного потенціалу ще не отримала належного наукового обгрунтування i вирішення, а управління бюджетним потенціалом усе ще не вирізняється комплексністю підходу та системністю розв'язання проблем, що в свою чергу впливає на вирішення пріоритетних задач, як економічного, так і соціального розвитку країни. Окреслена проблематика обумовлює потребу в продовженні досліджень в цій царині.

Формулювання цілей статті. Метою дослідження $\epsilon$ узагальнення теоретичних підходів сутності бюджетного потенціалу, встановлення теоретико-методологічних проблем та особливостей в цій сфері.

Опис основного матеріалу дослідження. Бюджетний потенціал відіграє ключову роль у соціально-економічному розвитку України, зокрема: будівництві мостів, доріг, фінансуванні освіти, охорони здоров'я, утриманні об'єктів житлово-комунального господарства, транспортної інфраструктури, соціального захисту малозабезпечених верств населення тощо. Виходячи $з$ тих завдань, які на нього покладаються, 3 самого 
початку стає зрозумілим, що необгрунтована політика його формування та використання, а також не врахування усіх особливостей негативно впливають як на можливості бюджету, зростання його потенціалу, так і на перспективи розвитку окремих територій, галузей економіки, соціальної сфери тощо. Тому, перш ніж досліджувати i обгрунтовувати значення i вагомість бюджетного потенціалу, варто 3'ясувати його сутність.

В економічній теорії та практичній діяльності поняття «потенціал» (від лат. potentia - сила, потужність), як правило, ототожнюється 3 такими термінами, як: запаси, резерви, інші можливості або засоби, що можуть бути використані в економічній діяльності суб'єкта господарювання. В Економічному енциклопедичному словнику [1, с.142], а також Економічній енциклопедії за редакцією С.В.Мочерного дається однакове визначення терміну «потенціал», як наявні в економічного суб'єкта ресурси, їх оптимальна структура та вміння раціонально використати їх для досягнення поставленої мети [2, с.13]. Виходячи з сутності даного терміну, поняття «потенціал» це ті ресурси, які перебувають у будь-якій формі в суб'єкта господарювання (реальній або умовній, скажімо кошти і знання, земля та досвід тощо). Завдання власника або управителя «потенціалу», раціонально використати його на конкретну ціль.

Аналізуючи економічну літературу, приходимо до висновку, що термін «потенціал» має досить широке значення і застосування, оскільки мова може йти про: природний, науковий, людський, технічний, економічний, інформаційний, військовий, інтелектуальний, національний потенціал тощо. Потенціал може бути уявний (потенційний) або фактичний (реальний). Якщо оцінювати потенціал в просторі або в часовому вимірі, то він може бути: минулий, поточний, перспективний (майбутній).

У сучасній економічній літературі дослідники характеризуючи потенціал бюджету (державного чи місцевого) часто вживають словосполучення «бюджетний потенціал». Хоча у бюджетному законодавстві, зокрема у Бюджетному кодексі України відсутнє трактування даного терміну [3]. Водночас на сьогодні за сприяння науковців існує велика кількість визначень поняття «бюджетний потенціал», деякі з них наведені в таблиці 1 .

Визначення терміну «бюджетний потенціал» та його похідних

Таблиця 1

\begin{tabular}{|c|c|c|}
\hline $\begin{array}{c}\text { Автор (и), } \\
\text { джерело }\end{array}$ & $\begin{array}{l}\text { термін, який } \\
\text { вживається }\end{array}$ & Визначення \\
\hline 1 & 2 & 3 \\
\hline $\begin{array}{c}\text { Бондарева О. Г. } \\
\text { [4] }\end{array}$ & $\begin{array}{l}\text { регіональний } \\
\text { бюджетний } \\
\text { потенціал }\end{array}$ & $\begin{array}{l}\text { є основоположний елемент формування, а в майбутньому - інструмент } \\
\text { розвитку фіскального простору країни. Цілеспрямовані дії уряду і місцевих } \\
\text { органів влади, які мають бюджетні повноваження відповідно до бюджетного } \\
\text { устрою держави, спрямовані на регулювання соціально-економічних показників } \\
\text { територій, ї інвестиційно - інноваційний розвиток та забезпечення економічної } \\
\text { безпеки, що призводить до зваженої фіскальної політики для всіх регіонів } \\
\text { країни. }\end{array}$ \\
\hline $\begin{array}{c}\text { Жебчук Р. Л. } \\
\text { [5] }\end{array}$ & $\begin{array}{c}\text { бюджетний } \\
\text { потенціал }\end{array}$ & $\begin{array}{l}\text { це частина фінансового потенціалу країни, адміністративно-територіальної } \\
\text { одиниці (області, району, міста, селища, села), що є загальним обсягом } \\
\text { грошових одиниць, які можуть бути акумульовані за рахунок усіх джерел в } \\
\text { бюджет адміністративно-територіального утворення за конкретний період часу } \\
\text { та за існуючих умов господарювання. }\end{array}$ \\
\hline $\begin{array}{c}\text { Крук O.M. } \\
\text { [6] }\end{array}$ & $\begin{array}{l}\text { бюджетний } \\
\text { потенціал } \\
\text { місцевого } \\
\text { бюджету }\end{array}$ & $\begin{array}{l}\text { слід розуміти потенційно можливу суму податкових та неподаткових } \\
\text { надходжень бюджетних доходів, які акумулюються за рахунок пошуку та } \\
\text { залучення додаткових джерел їх формування та можуть бути зібрані на певній } \\
\text { території в умовах чинного законодавства. }\end{array}$ \\
\hline $\begin{array}{c}\text { Педченко Н. С. } \\
\text { [7] }\end{array}$ & $\begin{array}{c}\text { бюджетний } \\
\text { потенціал регіону }\end{array}$ & $\begin{array}{l}\text { властивість бюджету забезпечувати перспективний соціально-економічний } \\
\text { розвиток регіону за допомогою наявних та невикористаних ресурсів, } \\
\text { сприятливих можливостей та існуючих здатностей. }\end{array}$ \\
\hline $\begin{array}{c}\text { Люта О.В. } \\
{[8]}\end{array}$ & $\begin{array}{c}\text { бюджетний } \\
\text { потенціал регіону }\end{array}$ & $\begin{array}{l}\text { сукупність реальних можливостей місцевих органів влади мобілізувати та } \\
\text { акумулювати в бюджеті відповідного регіону наявні та можливі для залучення } \\
\text { фінансові ресурси } 3 \text { метою забезпечення фінансування витрат місцевого } \\
\text { бюджету. }\end{array}$ \\
\hline $\begin{array}{l}\text { Волковський С.I., } \\
\text { Котіна Г.М., } \\
\text { Степура М. М. [9] }\end{array}$ & $\begin{array}{c}\text { бюджетний } \\
\text { потенціал } \\
\text { території }\end{array}$ & $\begin{array}{l}\text { це частина територіального фіскального простору, яка повністю належить } \\
\text { органам державного та територіального управління та може бути використана в } \\
\text { межах діючої моделі фіскального федералізму. Іншими словами, це та частина } \\
\text { виробленого на території продукту, яка централізується у державному та } \\
\text { місцевому фондах грошових коштів. } \\
\text { це та частина бюджетного потенціалу території і фіскального простору, яка } \\
\text { залишається на цьому рівні, враховуючи існуючі засади та інструменти } \\
\text { фіскального регулювання. }\end{array}$ \\
\hline
\end{tabular}




\begin{tabular}{|c|c|l|l|}
\hline \multicolumn{4}{|c|}{ Продовження табл. 1} \\
\hline
\end{tabular}

Аналіз наукової літератури дає можливість дослідити етимологію уявлень вчених про термін «бюджетний потенціал». Так, в залежності від сфери досліджень науковців цей термін має різне трактування i визначення, змінюючись під впливом специфічного бачення проблеми і точки зору дослідників.

Як видно 3 даних таблиці 1, значна кількість вчених досліджують питання «бюджетного потенціалу» 3 позиції його оцінки, значення i забезпечення окремих територій, міст, сіл, районів, регіонів, місцевого бюджету. Майже усі вони наголошують на необхідності комплексного підходу до оцінки його формування та ефективності використання. Деякі вважають, що він має бути «системним i враховувати комплекс характеристик» [8]. Жебчук Р.Л порівнює бюджетний потенціал 3 бюджетним плануванням відповідного бюджетного періоду і вважає, що бюджетний потенціал $\epsilon$ широким поняттям, в якому важливою, але не єдиною складовою $\epsilon$ податковий потенціал [5]. Деякі дослідники, вважають, що бюджетний потенціал є складовою фінансового та економічного потенціалу країни [9], ми, до речі, теж поділяємо цю точку зору.

Проведений нами аналіз теоретичного матеріалу 3 проблеми визначення бюджетного потенціалу свідчить, що більшість сучасних досліджень стосується окремих аспектів, зокрема:

- переважна більшість вчених схиляється до ресурсного підходу, визначаючи бюджетний потенціал, як можливість мобілізувати та акумулювати владою значний обсяг фінансових ресурсів, якими можна розпоряджатися, як на поточні потреби, так і на перспективи соціальноекономічного розвитку;

- деякі дослідники ототожнюють бюджетний потенціал в межах певного податкового простору [5], пошуку можливих неподаткових надходжень [6], взаємозв'язків [4], що виникають між учасниками;

- інші ототожнюють бюджетний потенціал, як сукупну здатність можливостей для досягнення цілей $[7 ; 8]$.
Підводячи підсумки аналізу різного тлумачення та інтерпретацій, можна виділити наступні характеристики даного поняття. Бюджетний потенціал, що ототожнюється 3 сукупністю фінансових ресурсів, не зовсім повний, адже якщо враховувати ресурсну концепцію, то таке визначення проявляється в двох формах: фактичній та умовно-абстрактній. 3 іншого боку, бюджетний потенціал $є$ радше характеристикою спроможності бюджету, яка відображається в його фінансовій складовій i проявляється в стійкості бюджету. Крім того, в бюджеті проявляється його специфічність, демонструючи не лише статистичні дані, а й характеризує як економічну категорію, яка виступає рушійною силою соціальноекономічного розвитку країни.

Беззаперечним є той факт, що бюджетний потенціал відіграє ключову відтворювальну функцію, забезпечуючи зростання, як фінансового так i загальноекономічного потенціалу країни. Сприяє стійкості фінансової та економічної систем, забезпечує конкурентоздатність вітчизняних підприємств, товарів, послуг на внутрішньому та зовнішньому ринках, допомагає суб'єктам господарювання розширювати економічні можливості, сприяє зростанню ВВП та добробуту громадян.

Критично осмислюючи та аналізуючи сучасні теоретичні підходи, ми пропонуємо розглядати бюджетний потенціал як динамічне поєднання фактичних (реалізованих) та «нереалізованих» можливостей. В цьому контексті, ми розглядаємо бюджетний процес, що нерозривно пов'язаний 3 бюджетним потенціалом, як гнучку, динамічну i досить складну систему, яка об'єднує в собі різні відносини та зв'язки, тимчасові характеристики та простір, певні закономірності та перспективи розвитку. Поєднуючи в собі різноманітні елементи та властивості, бюджетний потенціал набуває характерного, ресурсного значення. Він несе в собі особливу рису щодо практичного застосування та використання усіх наявних можливостей $\mathrm{i}$ розмежовує реалізовані та «нереалізовані» можливості.

Бюджетний потенціал несе в собі певне значення, так би мовити має потенційний 
«резерв». До речі, в економічній літературі, зокрема в бюджетній сфері застосовується термін «бюджетний резерв», який означає наперед зарезервована частина бюджетних коштів, призначена для фінансування різних непередбачених витрат держави [11, с.394]. Проте в нашому випадку, ми вкладаємо дещо інший зміст в цей термін. Тут, ми маємо на увазі ті можливості, які з різних причин не задіяні у формуванні бюджетного потенціалу, а отже «резерв» має потенційний характер i не використовується у економічному відтворенні, наприклад через законодавчу неврегульованість, корупційну складову або інші шахрайські дії деяких учасників бюджетного процесу.

Бюджетний потенціал, поєднуючи мінливий та стійкий стан, містить елементи майбутнього, які в переспективі використовуються на конкретні цілі і зорієнтовані на подальший економічний та соціальний розвиток.

На наш погляд, бюджетний потенціал це сукупність реальних та умовних можливостей, які визначаються чинним бюджетним законодавством на певному економічному просторі або території (країни, регіону, області, міста, села). Бюджетний потенціал $\epsilon$ центральною ланкою взаємовідносин між рівнями бюджетної системи та іiі фінансовим ресурсозабезпеченням на відповідному економічному просторі. Він $\epsilon$ складовою фінансового та економічного потенціалу країни, а його здатність, можливості та наявні ресурси використовуються передусім на реалізацію стратегії економічного та соціального розвитку країни та покращення добробуту громадян.

Від ефективного використання наявного бюджетного потенціалу залежить динаміка соціально-економічного розвитку країни, надання громадянам якісних i в достатній кількості суспільних благ і послуг. За умов зростання економіки стимулюється попит, розширюються можливості бюджетного потенціалу зростає його ресурсна складова, що позитивно впливає на підвищення соціальних стандартів в країні, рівень і якість життя громадян.

Бюджетний потенціал визначається фактично його реальними фінансовими можливостями, тобто тими ресурсами, які закладаються в бюджет при його формуванні. Бюджетний потенціал уособлює в собі не лише реалізовані можливості, а також й «нереалізовані» 3 будьяких причин. Що це означає на практиці?

Так, сучасні тенденції використання бюджетного потенціалу свідчать, що ресурси бюджету (державного чи місцевого) не завжди використовуються цілеспрямовано, тобто на конкретну мету. Наприклад, якщо проаналізувати стан виконання Державного бюджету України будь-якого бюджетного періоду, то побачимо, що навіть той бюджетний потенціал, який сформовано i фактично закладено в бюджеті, використовується неефективно та не раціонально, а це означає, що бюджетний потенціал розпорошується i конкретна мета, яка закладається в різноманітних бюджетних програмах, не досягається. Таким чином, маємо ситуацію, яку ми характеризуємо, як «нереалізовані» можливості використання бюджетного потенціалу. Причиною виникнення «нереалізованих» можливостей $є$ : неефективне, незаконне, в тому числі нецільове використання бюджетних коштів (рис.1).

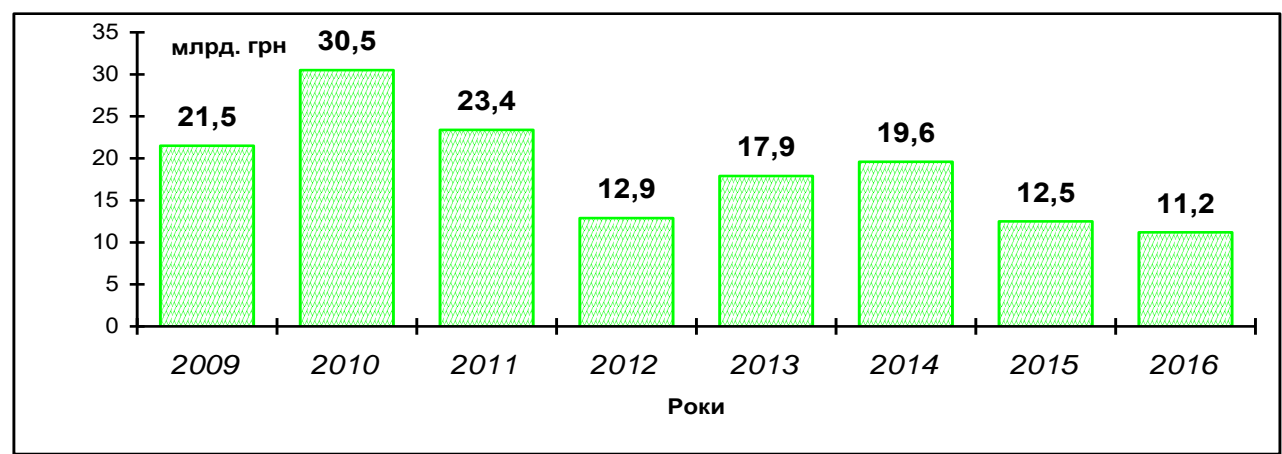

Рис.1 Неефективне, незаконне, в тому числі нецільове використання бюджетних коштів*

* Побудовано автором за даними річних Звітів Рахункової палати [12-19]

Як видно з даних рисунка 1, щорічні обсяги неефективного, незаконного, у тому числі нецільового використання бюджетних коштів хоч змінюються в сумах, проте досить великі за розмірами. Крім того, «нереалізовані» можлості» суттєво підривають спроможність бюджетного потенціалу, його вагомість i значення $\mathrm{y}$ соціально-економічному розвитку. Наприклад, у переорієнтації вітчизняних підприємств до ринкових умов, освоєння нових ринків збуту, нарощування валових обсягів продукції та збільшення товарів 3 високою часткою доданої 
вартості. Тобто, стримується процес становлення «нової» економіки, розбудови соціальної інфраструктури тощо.

Ми вважаємо, що «нереалізовані можливості» по-суті є втратами бюджету. Адже бюджетний потенціал через незаконне, не раціональне, неефективне його використання з самого початку не виконав того завдання, яке покладалось на нього, і потенціал не досяг мети. Наприклад, закупівля медичного обладнання, яке вже закуплене, проте довгий час (1-2 роки) простояло під відкритим небом або у непристосованому для зберігання приміщенні, означає, що держава, область, регіон чи місто не отримали суспільної користі або економічної вигоди, а бюджетні кошти втрачені назавжди. Адже, $\epsilon$ велика ймовірність втрати або псування (під дією атмосферних опадів) окремих деталей або виходу з ладу цілих електронно-обчислювальних блоків, а фірма-постачальник не буде нести відповідальності за монтаж і подальшу надійну експлуатацію даного устаткування.
Таким чином, виходячи з сучасних реалій, необхідно при оцінці використання бюджетного потенціалу розподіляти його на дві складові: реалізовані та «нереалізовані можливості» (рис.2). Що це дає? По-перше, об'єктивно оцінити ефективність та результативність бюджетного потенціалу при його використанні. По-друге, відображаючи «нереалізовані можливості», наприклад через 3MI, Internet, стимулювати розпорядників коштів до ефективного використання бюджетного потенціалу та недопущення подібних випадків у майбутньому. По-третє, відкрито заявляючи про проблеми у бюджетній сфері, держава стимулюватиме інституційні зміни в суспільстві. Наприклад, залучення широкої громадськості до обговорення болючих бюджетних проблем сприятиме ліквідації недовіри суспільства до влади, формування незалежного інституту громадського контролю та його активної участі у бюджетному процесі, що позитивно вплине на якість бюджетного процесу i використання бюджетного потенціалу.

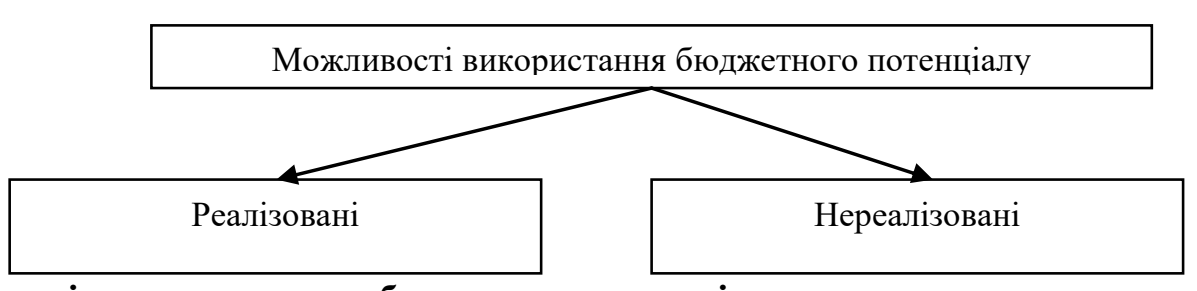

\section{Рис.2. Розподіл використаного бюджетного потенціалу за одержаними результатами* \\ * Розроблено автором}

Крім того, базисна основа і спроможність бюджетного потенціалу залежать не лише від наявних фінансових ресурсів, а також «прихованих резервів» (рис.3), які з будь-яких причин не задіяні у процесі формування бюджетного потенціалу (наприклад, через не врегульоване законодавство, відсутність механізмів його залучення до бюджетного потенціалу тощо). Таким чином, «прихований резерв» залишається поза відтворювальним процесом або долучається до нього через застосування відповідних інструментів законодавчо-нормативного впливу.

Наповнення бюджету фінансовими ресурсами i ефективність використання бюджетного потенціалу визначаються не лише наявними грошовими коштами (фінансовими ресурсами) та можливостями. В цьому контексті важливу роль відіграють професійні навички, майстерність, вміння державних службовців приймати вчасні, кваліфіковані управлінські рішення.

Ефективність та результативність використання бюджетного потенціалу оцінюється якісними соціальними послугами, товарами, виконаними будівельними роботами тощо. Важливим чинником ефективного використання бюджетного потенціалу є отримання державою економічної вигоди, доходу (прибутку), а також створення комфортних умов для кращого життя громадян, наприклад, через забезпечення населення: чистою питною водою, очисними спорудами в містах, сучасною соціальною, дорожньо-транспортною інфраструктурою тощо.

Результативність бюджетного потенціалу i рівень ефективності його використання визначаються підприємницьким хистом державних службовців, їх вмінням ефективно використати бюджетний потенціал, створеною організаційно-управлінською структурою, яка допомагає приймати ефективні управлінські рішення i отримувати максимально високий результат при реалізації бюджетного потенціалу.

Формування сучасних умов соціальноекономічного розвитку України неможливе без удосконалення бюджетних відносин. Останне неможливе без комплексного i системного дослідження сутності бюджетного потенціалу, а також розкриття усіх його структурних 
елементів. Натомість структурними елементами бюджетного потенціалу є: - фінансова складова, тобто бюджетні ресурси; - можливості, власне наявні «резерви», в тому числі з різних причин приховані.

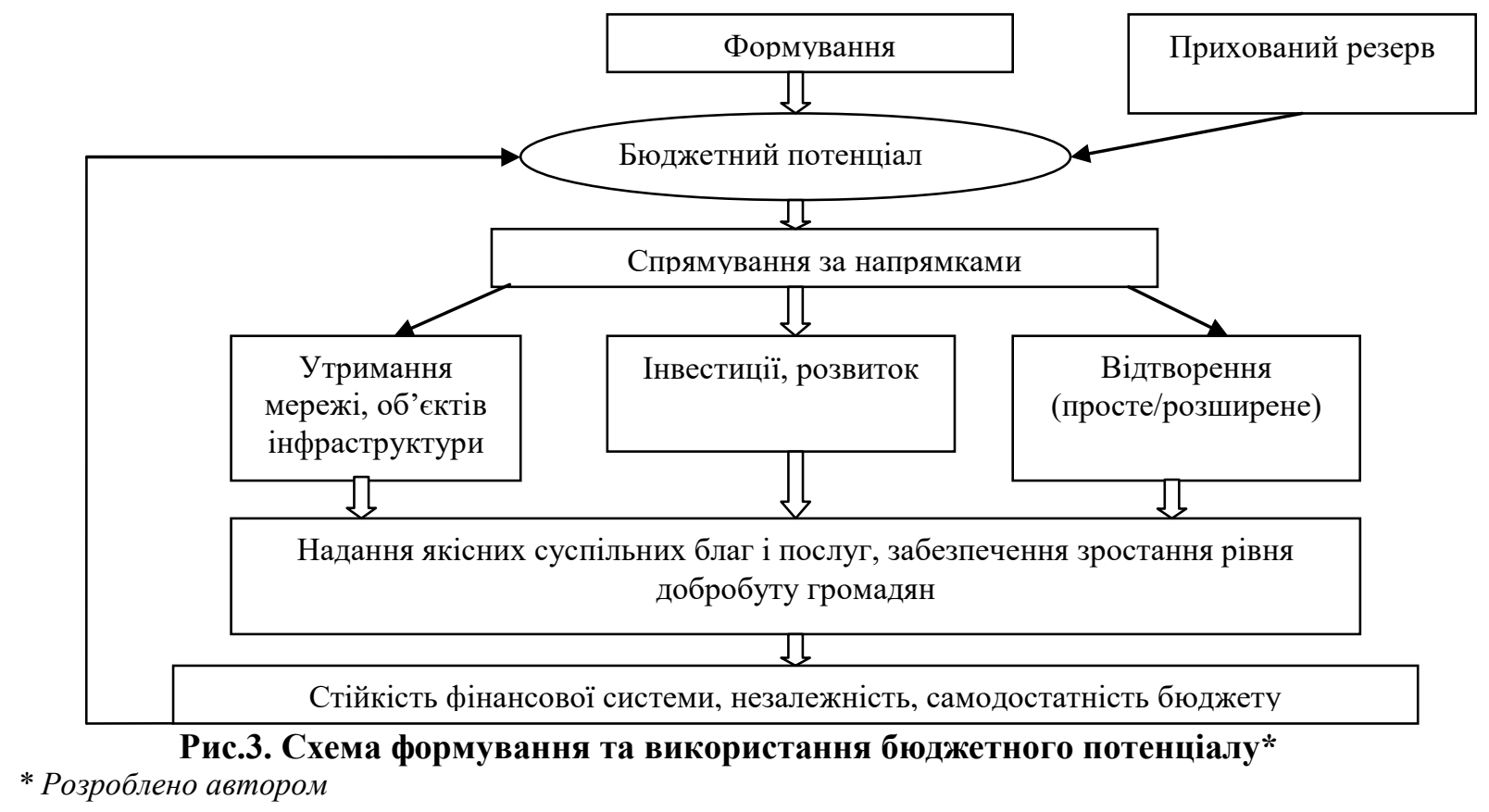

Чинниками, які впливають на виникнення «прихованого резерву», який з різних причин не враховується при формуванні бюджетного потенціалу, є: законодавча неврегульованість, шахрайство, корупція. Найбільші обсяги «прихованого резерву» $\epsilon$ в тих країнах, де нерозвинені або слабо розвинені демократичні інститути, не працює система громадського контролю, а суспільство не приймає активної участі в соціально-економічних процесах країни. Тобто, нерозвиненість демократичних інститутів, прямо пропорційно впливає на ефективність адміністрування податків і зборів, які формують основу бюджетного потенціалу.

Наочним прикладом слабкої інституційної складової $є$ недостатньо ефективна робота посадових осіб i інституцій (державних структур), i це добре видно на прикладі аудиторських перевірок.

Так, аудит ефективності виконання повноважень територіальними органами Державної фіскальної служби у Одеській, Миколаївській та Херсонській областях в частині контролю за повнотою нарахування та своєчасністю сплати до державного бюджету митних платежів суб'єктами підприємницької діяльності засвідчив ряд проблем у сфері митного контролю. Встановлено, що Одеською, Миколаївською та Херсонською митницями через відсутність координації роботи та дієвих управлінських рішень з боку ДФС (Міндоходів) упродовж 2014-2015 років і I кварталу 2016 року не забезпечено виконання доведених індикативних показників надходжень митних платежів до державного бюджету, внаслідок чого до бюджету не надійшло 1 млрд 172 млн грн, у тому числі по Одеській митниці - 1 млрд 130,4 млн гривень [19, с.210].

Результати аудиту ефективності забезпечення органами Державної фіскальної служби повноти та своєчасності сплати (стягнення) штрафних санкцій i пені до державного бюджету засвідчили, що ДФС (Міндоходів, ДПС) протягом 2013-2015 років не забезпечено системного, дієвого контролю за застосуванням (нарахуванням) та сплатою (стягненням) до державного бюджету штрафів і пені при виявленні правопорушень, відповідальність за які встановлено Податковим кодексом України. Встановлено, що за результатами документальних перевірок платників податків юридичних осіб у 2013-2015 роках донараховано грошових зобов'язань на суму 73,2 млрд грн, а сплачено (стягнуто) до бюджету лише 12,5 млрд гривень. За розрахунками сума штрафів, застосованих за результатами таких перевірок, становила 18,5 млрд грн, 3 яких сплачено (стягнуто) до бюджету лише 3,1 млрд гривень. У дослідженому періоді внаслідок низького рівня сплати застосованих (нарахованих) сум штрафів i пені недонадходження до державного бюджету становили близько 20 млрд грн, 3 них за узгодженими сумами - понад 4 млрд гривень [19, c.212].

Результати аудиту ефективності справляння та дієвості контролю за надходженням рентної 
плати за користування надрами для видобування нафти до державного бюджету засвідчили, що протягом 2014-2015 років та I півріччя 2016 року органи державної влади не забезпечили створення ефективної та дієвої системи державного контролю за обсягами видобутку нафти, яка $є$ об'єктом оподаткування рентною платою за користування надрами для видобування нафти, а також за повнотою i своєчасністю надходження цього платежу до державного бюджету. Так, до державного бюджету надійшло загалом майже 10 млрд грн рентної плати за користування надрами для видобування нафти. Водночас частка надходжень цього платежу у загальних обсягах надходжень до державного бюджету рентної плати за користування надрами для видобування корисних копалин скоротилася з 32,7 відс. у 2014 році до 7,9 відс. у I півріччі 2016 року. За 2,5 роки податковий борг із зазначеного платежу збільшився в 606 разів - 3 10,5 млн грн станом на 01.01.2014 до 6 млрд 363,1 млн грн станом на 01.07.2016, 3 яких майже 98,6 відс. обліковувалися за ПАТ «Укрнафта». У 2014 році ДФС (Міндоходів) забезпечила виконання планових показників надходження до держбюджету на рівні 95,7 відс., то у 2015 році лише на 44,8 відсотка. Загалом до держбюджету не надійшло понад 3,5 млрд грн зазначеного платежу. У 2016 році ситуація ще погіршилася: за 10 місяців органи ДФС забезпечили виконання плану лише на 36,2 відсотка [19, с.216-217].

Наповнення доходної частини бюджету, власне формування основи бюджетного потенціалу, дуже важливий чинник, адже він визначає його спроможність. Крім того, це динамічний, безперервний процес, який певною мірою визначає можливості при його використанні. Процес формування включає в себе прийняття низки управлінських рішень (тактичних, стратегічних, поточних), націлених на збалансованість бюджету, сталість економічного i соціального розвитку. Досить часто процес формування бюджетного потенціалу підпадає під дію різних факторів: невизначеності, ризику, внутрішніх i зовнішніх викликів. Наприклад, бюджетний потенціал досить важко визначити в умовах нестабільної економіки, коливань ринкової кон'юнктури, відсутності економічних стимулів у підприємців до високопродуктивної праці. Якщо не здійснюється модернізація та технологічне переобладнання застарілого виробництва на підприємствах, то неможливо сподіватись i на зростання бюджетного потенціалу та його спроможності.

Наприклад, за умов розвинутої корупції, тінізації економіки, відсутності правових механізмів захисту інвестор не буде фінансувати ризиковані проекти в економіці, соціальній сфері або екології. Корупційний чинник негативно відображається не лише на розвитку малого та середнього бізнесу, реального сектору, а також на доходах бюджетів усіх рівнів, що підриває основу бюджетного потенціалу.

Між тим, на формування базових складових бюджетного потенціалу впливають: рівень прибутковості вітчизняних підприємств, досвід i навички їх керівництва працювати в умовах ринкової економіки, нормативно-правова врегульованість питань ведення бізнесу тощо. Важливою є також ієрархічна система управління, реагування на виклики та загрози, в тому числі вирішення назрілих соціально-економічних проблем. Зазвичай, конкурентоспроможність вітчизняних підприємств забезпечується через розвиненість фінансової інфраструктури (сервіси, послуги тощо), рівень розвитку науково-технічного прогресу, інформаційнотехнологічне забезпечення та зовнішні фактори: вплив глобалізації, рівень політичної довіри в суспільстві до правлячої еліти тощо.

3 іншого боку, обмеженість бюджетних коштів, що спостерігається в Державному бюджеті України, тим паче в умовах відсутності середньострокового прогнозування (на 3-5 років), не дають можливості планувати довгострокову економічну діяльність: вирішувати як поточні, так і стратегічні завдання соціально-економічного розвитку.

Крім того, на формування бюджетного потенціалу впливає грошово-кредитна політика держави, адже високі ставки за кредитами не дають можливість залучати у виробничий процес банківські кредити, а не розвиненість фінансової інфраструктури стримує залучення вільних фінансових ресурсів на потреби економіки та соціальної сфери. Ці чинники також негативно впливають на зростання ВВП та рівень життя населення.

Зазвичай процес формування бюджетного потенціалу вибудовується за параметрами врахування усіх чинників та зростання економіки, досягнення високих результативних показників, збільшення фінансових ресурсів, що в грошовій формі надходять до бюджету. Тому, науковообгрунтоване планування $є$ важливим чинником виявлення можливостей бюджетного потенціалу.

Окрім закріплених податків та зборів на показники бюджетного потенціалу, його можливості впливає також залучення «прихованих резервів», які в силу різних обставин не приймають участь в формуванні бюджетного потенціалу. 
Ми вважаємо, що бюджетний потенціал (БП), необхідно розраховувати за такою формулою:

$$
\text { БП = ПП+НПП+IM, }
$$

де ПП - податковий потенціал на даному економічному просторі, НПП - неподатковий потенціал. Необхідно, також враховувати інші можливості (IM), які зазвичай $€$ на даному економічному просторі для наповнення бюджету, виходячи 3 реальних та потенційних спроможностей бюджету.

Оцінку бюджетного потенціалу - БП(о) слід розраховувати за формулою:

$$
\text { БП }(\mathrm{o})=\text { БП }(ф): \text { БЗ, }
$$

де БП (ф) - фактичний бюджетний потенціал, необхідно розділити на бюджетні зобов'язання (Б3) у відповідному бюджетному періоді на даному економічному просторі. Такий підхід, на наш погляд, дає можливість реально оцінити спроможність бюджету, враховуючи структуру економіки, виробничі, невиробничі, оборотні фонди, патенти, ліцензії, технології, людські, природні, наукові, фінансові ресурси, інвестиційну привабливість на даній території тощо. Крім того, це дає можливість встановити існуючі проблеми, зокрема отримати відповідь на такі питання: який рівень бюджетного потенціалу, чи самодостатній i незалежний він на даній території?

На наш погляд, сутність бюджетного потенціалу визначається єдністю можливостей та реальними ресурсами, власне тими коштами, які $\epsilon$ в усієї бюджетної системи. Оскільки фінансові ресурси передаються з одного рівня бюджету до іншого (через міжбюджетні трансферти). Тобто, бюджетний потенціал також певною мірою залежить від ресурсів i можливостей як державного, так i місцевих бюджетів. Якщо місцевий бюджет є дотаційним то через систему міжбюджетних відносин цей бюджет отримує певну частку міжбюджетних трансфертів, наприклад 3 державного бюджету. Таким чином забезпечується збалансованість бюджетної системи i підтримка місцевих бюджетів для вирішення певних проблем на окремій території чи населеному пункті.

Рівень забезпеченості фінансовими ресурсами як основою бюджетного потенціалу залежить не тільки від результативності реального сектору економіки, що безумовно впливає на формування базової основи та нарощування бюджетного потенціалу, а також від грамотної та ефективної бюджетної політики щодо використання ресурсів, які входять до складу бюджетного потенціалу та механізмів їх примноження.

Ефективність використання бюджетного потенціалу забезпечується шляхом якісного управління наявними фінансовими ресурсами в межах комплексної системи управління потенціалом як при формуванні так i використанні бюджетного потенціалу.

Бюджетний потенціал визначає спроможність бюджету, ступінь його незалежності та самостійності. Якщо бюджет дотаційний, то це обмежує можливості утримувати об'єкти соціальної інфраструктури, не говорячи про вирішення складних соціально-економічних проблем та досягнення стратегічних цілей розвитку.

Ефективне використання бюджетного потенціалу в межах міста, села, окремої території має враховувати вектор економічного та соціального розвитку країни. Адже бюджетний потенціал не може використовуватись одноосібно, а лише в рамках усієї бюджетної політики за різними напрямками, які узгоджені із загальною економічною політикою. Саме в цьому контексті визріває чітке розуміння певних факторів, а саме пріоритети розвитку і на якому рівні (державний, регіональний (обласний), місцевий), вони мають бути реалізовані. В рамках загальнодержавної економічної та бюджетної політики йде перерозподіл функцій державної влади і повноважень. Тобто, яка кількість ресурсів і 3 якого бюджету має виділятись на вирішення тих чи інших проблем, напрямків i пріоритетів. Такий підхід в формуванні i використанні бюджетного потенціалу дає можливість уникати розпорошення фінансових ресурсів і сприятиме досягненню кращих результативних показників, отримання доходу (прибутку), забезпечення фінансової стійкості, підвищення соціальних стандартів, зростання добробуту громадян.

Критерієм, який демонструватиме ефективне використання бюджетного потенціалу, може бути стала динаміка економічного зростання, осучаснення соціальної інфраструктури, розширення мережі суспільних благ і послуг. Комплексний критерій оцінювання ефективності використання бюджетного потенціалу дозволяє застосовувати системність і відслідковувати роль i значення кожного бюджету (державного, місцевого), вчасно виправляти помилки i сприяти зростанню можливостей бюджетного потенціалу. В цій ситуації важливо також визначити систему об'єктивних показників, які дали б можливість неупереджено оцінити ефективність використання бюджетного потенціалу.

Висновки i перспективи подальших досліджень. Проведене дослідження дає підстави стверджувати, що бюджетний потенціал відіграє важливу роль у соціально-економічному розвитку України. Аналіз теоретикометодологічних проблем формування i 
використання бюджетного потенціалу має теоретичне та практичне значення, оскільки дає можливість розкривати «приховані резерви». Вчасно виявляти їх та встановлювати інші проблеми формування i використання бюджетного потенціалу, в тому числі уникати можливих ризиків та забезпечувати збалансованість усієї бюджетної системи України.

Актуальним i важливим $\epsilon$ відображення в Бюджетному кодексі України терміну «бюджетний потенціал». Необхідно передбачити щорічну оцінку ефективності використання бюджетного потенціалу. При оцінці розподіляти результати на дві категорії: «реалізовані» та «нереалізовані» можливості. До останньої категорії або критерію оцінки варто включати неефективне, незаконне, в тому числі, нецільове використання бюджетних коштів. Це дасть можливість, чіткіше структурувати бюджетні витрати, об'єктивно оцінювати результати використання бюджетного потенціалу. Крім того, запропоновані заходи мають стати важливим чинником поширення транспарентності в бюджетній системі, демократизації суспільства та формування нових соціально-економічних інститутів, підвищення можливостей бюджетного потенціалу, напрацюванні механізмів прийняття вчасних, обгрунтованих управлінських рішень усіма учасниками бюджетного процесу.

\section{ПЕРЕЛІК ВИКОРИСТАНИХ ДЖЕРЕЛ}

1. Мочерний С.В., Ларіна Я.С., Устенко О.А., Юрій С.І. Економічний енциклопедичний словник: У 2 т.Т.2 /За ред. С.В.Мочерного. - Львів: Світ, 2006. - 568c.

2. Економічна енциклопедія: У трьох томах. Т.3/ Редкол.....С.В.Мочерний (відп.ред.). та ін. - К.: Видавничий центр «Академія», 2002. - 952c.

3. Бюджетний кодекс України від 08.07.2010 №2456-V [Електронний ресурс] - Режим доступу: http://zakon2.rada.gov.ua/laws/show/2456-17/page13

4. Бондарева О. Г. Бюджетний потенціал регіону як основа фіскального простору України / О. Г. Бондарева // Часопис економічних реформ. - 2013. - № 4. - С. 86-90. - Режим доступу: http://nbuv.gov.ua/UJRN/Cher_2013_4_16.

5. Жебчук Р. Л. Бюджетний потенціал та його місце в процесі бюджетного планування / Р. Л. Жебчук // Вісник Одеського національного університету. Економіка. - 2013. - Т. 18, Вип. 3(1). - С. 144-147. - Режим доступу: http://nbuv.gov.ua/UJRN/Vonu_econ_2013_18_3(1)_38

6. Крук О.М. Формування та оцінка бюджетного потенціалу місцевого бюджету [Електронний ресурс] Режим доступу: http://www.dgma.donetsk.ua/science_public/ddma/2012-2-27/article/12KENPLB.pdf

7. Педченко Н.С. Бюджетний потенціал регіону: оцінка та перспективи розвитку : монографія / Н. С. Педченко, В. Ю. Стрілець. - Полтава : ПУЕТ, 2014. - 220 с. (стор.17)

8. Люта О.В. Бюджетний потенціал як визначальний чинник фінансового забезпечення розвитку регіону [Електронний ресурс] - Режим доступу: http://www.economy.nayka.com.ua/?op=1\&z=2584

9. Волковський Є. І. Бюджетний потенціал та потенціал бюджету території: методичні аспекти / Є. І. Волковський, Г. М. Котіна, М. М. Степура // Проблеми економіки. - 2014. - № 4. - С. 357-362. - Режим доступу: http://nbuv.gov.ua/UJRN/Pekon_2014_4_49.

10. Мельник Л.М., Дума В.Л. Сутність, природа та особливості формування бюджетного потенціалу на регіональному рівні. Бізнесінформ №12, 2015. [Електронний ресурс] - Режим доступу: http://businessinform.net/export_pdf/business-inform-2015-12_0-pages-276_281.pdf

11. Загородній А.Г., Вознюк Г.Л., Смовженко Т.С. Фінансовий словник. - 3-те вид., випр. та доп. - К.: Т-во «Знання», КОО, 2000. - 587c.

12. Звіт Рахункової палати України за 2009 рік [Електронний ресурс] - Режим доступу: http:// www.acrada.gov.ua /doccatalog/document/16741917/Zvit_2009.pdf

13. Звіт Рахункової палати України за 2010 рік [Електронний ресурс] - Режим доступу: http:// www.acrada.gov.ua /doccatalog/document/16741918/Zvit_2010.pdf

14. Звіт Рахункової палати України за 2011 рік [Електронний ресурс] - Режим доступу: http:// www.acrada.gov.ua /doccatalog/document/16740480/Zvit_2011.pdf

15. Звіт Рахункової палати України за 2012 рік [Електронний ресурс] - Режим доступу: http:// www.acrada.gov.ua /doccatalog/document/16742074/Zvit_2012.pdf

16. Звіт Рахункової палати України за 2013 рік [Електронний ресурс] - Режим доступу: http:// www.acrada.gov.ua /doccatalog/document/16744990/Zvit_2013.pdf

17. Звіт Рахункової палати України за 2014 рік [Електронний ресурс] - Режим доступу: http:// www.acrada.gov.ua /doccatalog/document/16747166/Zvit_2014.pdf

18. Звіт Рахункової палати України за 2015 рік [Електронний ресурс] - Режим доступу: http:// www.acrada.gov.ua /doccatalog/document/16748714/Zvit_RP_2015.pdf

19. Звіт Рахункової палати України за 2015 рік [Електронний ресурс] - Режим доступу: http:// www.acrada.gov.ua /doccatalog/document/16751480/Zvit_RP_2016.pdf 


\section{REFERENCES}

1. Mocherny, S.V. Larina, Ya.S. Ustenko, O.A. Yuriy, S.I. (2006). Ekonomichniy entsiklopedichniy slovnik [Economic Encyclopedic Dictionary]. (Vol.2), Lviv, World [in Ukrainian].

2. Mocherny, S.V. (Eds.) (2002). Ekonomichna entsiklopediya [Economic Encyclopedia: In three volumes]. (Vol.3), Kyiv, Publishing Center "Academy" [in Ukrainian].

3. Byudgetniy kodex Ukrainy: zakon Ukrainy №2456-V vid 08.07.2010. [Budget Code of Ukraine, from July 08 2010 №2456-V] (2017, August 17). zakon.rada.gov.ua Retrieved from: http://zakon2.rada.gov.ua/laws/show/245617/page13 [in Ukrainian].

4. Bondareva, O. G. (2013). Byudzhetniy potentsial regionu yak osnova fiskal'nogo prostoru Ukrainy [The budget potential of the region as the basis of the fiscal space of Ukraine]. Chasopis ekonomichnih reform - The Journal of Economic Reforms, 4, 86-90. - Access mode: http://nbuv.gov.ua/UJRN/Cher_2013_4_16. [in Ukrainian].

5. Zhebchuk, R.L. (2013). Byudzhetniy potentsial ta yogo mistse v protsesi byudzhetnogo plnuvan'ya [Budgetary potential and its place in the process of budget planning]. Visnik Odes 'kogo natsional'nogo universitetu - Bulletin of the Odessa National University. Economy, Vol. 18, 3 (1),144-147. Retrieved from: http://nbuv.gov.ua/UJRN/Vonu_econ_2013_18_3(1)_38 [in Ukrainian].

6. Kruk, O.M. (2012). Formuvan'ya ta otsinka byudzhetnogo potentsialu mistsevogo byudzhetu [Formation and assessment of the budget potential of the local budget]. Retrieved from: http://www.dgma.donetsk.ua/science_public/ddma/2012-2-27/article/12KENPLB.pdf [in Ukrainian].

7. Pedchenko, N.S. Strilets', V.Yu. (2014). Byudzhetniy potentsial regionu: otsinka ta perspektivy rozvitku [The budget potential of the region: assessment and development prospects]. Poltava. [in Ukrainian].

8. Lyuta, O.V. (2014). Byudzhetniy potentsial yak viznachal'niy chinnik finansovogo zabezpechenn'ya rozvitku regionu [Budget potential as a defining factor for financial provision of the region's development]. Retrieved from: http://www.economy.nayka.com.ua/?op=1\&z=2584 [in Ukrainian].

9. Volkovsky, Ye.I. (2014). Byudzhetiy potentsial ta potentsial byudzhetu teritorii: metodichni aspekti [Budget potential and potential of the territory budget: methodological aspects]. Problemi ekonomiki - Problems of Economics, 4, 357-362. Retrieved from: http://nbuv.gov.ua/UJRN/Pekon_2014_4_49. [in Ukrainian].

10. Melnik, L.M. Duma, V.L. (2015). Sutnist', priroda ta osoblivosti formuvann'ya byudzhetnogo potentsialu na regional'nomu rivni [The essence, nature and features of budget capacity building at the regional level]. Biznesinform, 12, Retrieved from: http://business-inform.net/export_pdf/business-inform-2015-12_0-pages-276_281.pdf [in Ukrainian].

11. Zagorodniy, A.G. Voznyuk, G.L. Smovzhenko, T.S. (2000). Finansoviy slovnik [Financial Dictionary. - 3rd type. and add]. Kyiv, "Knowledge" [in Ukrainian].

12. Accounting Chamber of Ukraine (2009). Zvit Rahunkovoyi palati za 2009 rik [Report of the Accounting Chamber in 2009] Accounting Chamber of Ukraine, adopted on 2010. Retrieved from: http:// www.ac-rada.gov.ua /doccatalog/document/16741917/Zvit_2009.pdf [in Ukrainian]

13. Accounting Chamber of Ukraine (2010). Zvit Rahunkovoyi palati za 2010 rik [Report of the Accounting Chamber in 2010] Accounting Chamber of Ukraine, adopted on 2011. Retrieved from: http:// www.ac-rada.gov.ua /doccatalog/document/16741918/Zvit_2010.pdf [in Ukrainian]

14. Accounting Chamber of Ukraine (2011). Zvit Rahunkovoyi palati za 2011 rik [Report of the Accounting Chamber in 2011] Accounting Chamber of Ukraine, adopted on 2012. Retrieved from: http:// www.ac-rada.gov.ua /doccatalog/document/16740480/Zvit_2011.pdf [in Ukrainian]

15. Accounting Chamber of Ukraine (2012). Zvit Rahunkovoyi palati za 2012 rik [Report of the Accounting Chamber in 2012] Accounting Chamber of Ukraine, adopted on 2013. Retrieved from: http:// www.ac-rada.gov.ua /doccatalog/document/16742074/Zvit_2012.pdf [in Ukrainian]

16. Accounting Chamber of Ukraine (2013). Zvit Rahunkovoyi palati za 2013 rik [Report of the Accounting Chamber in 2013] Accounting Chamber of Ukraine, adopted on 2014. Retrieved from: http:// www.ac-rada.gov.ua /doccatalog/document/16744990/Zvit_2013.pdf [in Ukrainian]

17. Accounting Chamber of Ukraine (2014). Zvit Rahunkovoyi palati za 2014 rik [Report of the Accounting Chamber in 2014] Accounting Chamber of Ukraine, adopted on 2015. Retrieved from: http:// www.acrada.gov.ua/doccatalog/document/16747166/Zvit_2014.pdf [in Ukrainian]

18. Accounting Chamber of Ukraine (2015). Zvit Rahunkovoyi palati za 2015 rik [Report of the Accounting Chamber in 2015] Accounting Chamber of Ukraine, adopted on 2016. Retrieved from: http:// www.acrada.gov.ua/portal.rp.int/doccatalog/document/16748714/Zvit_RP_2015.pdf [in Ukrainian]

19. Accounting Chamber of Ukraine (2016). Zvit Rahunkovoyi palati za 2016 rik [Report of the Accounting Chamber in 2016] Accounting Chamber of Ukraine, adopted on 2017. Retrieved from: http:// www.ac-rada.gov.ua /doccatalog/document/16751480/Zvit_RP_2016.pdf [in Ukrainian]

Одержано 18.08.2017 p. 